\title{
Arthroscopic limited intercarpal fusion without bone graft in patients with Kienböck's disease
}

\author{
Kienöck hastalığı olan hastalarda kemik grefti olmaksızın \\ artroskopik kısmi interkarpal füzyon
}

\author{
Kadir Ertem, MD., ${ }^{1}$ Gökay Görmeli, MD., ${ }^{1}$ Mustafa Karakaplan, MD., ${ }^{1}$ \\ Okan Aslantürk, MD., ${ }^{1}$ Yunus Karakoç, MD. ${ }^{2}$ \\ 'Department of Orthopedics and Traumatology, Medical Faculty of İnönü University, Malatya, Turkey \\ ${ }^{2}$ Department of Biophysics, Medical Faculty of İnönü University, Malatya, Turkey
}

\section{ABSTRACT}

Objectives: This study aims to present our clinical results obtained in arthroscopic limited intercarpal fusion performed without using bone graft in patients with Kienböck's disease.

Patients and methods: The study included 11 patients with Kienböck's disease (6 males, 5 females; mean age 28.9 years; range 14 to 51 years) who were performed arthroscopic lunate excision and scaphocapitate fusion between November 2012 and December 2013. Bain and Begg Arthroscopic Classification was used for the staging of Kienböck's disease. Quick Disabilities of Arm, Shoulder and Hand and Mayo Wrist scorings were used for clinical evaluation.

Results: Intercarpal fusion was achieved in approximately 7.2 weeks. There was a statistically significant difference in Mayo Wrist scores of postoperative third and sixth months and pre- and postoperative Quick Disabilities of Arm, Shoulder and Hand scores. There was no postoperative complication.

Conclusion: According to our study findings, arthroscopic limited intercarpal fusion without using bone graft may be performed in patients with Kienböck's disease. Satisfactory clinical and functional results were obtained as a result of treatment with this method in stage 3 and 4 Kienböck's disease.

Keywords: Arthrodesis; arthroscopy; Kienböck's disease; midcarpal fusion; wrist.

Kienböck's disease is a progressive, debilitating disease that can lead to chronic wrist pain with significant limitations like other carpal bone problems. ${ }^{[1,2]}$ Despite its definition nearly 100 years ago, the etiology is still
ÖZ

Amaç: $\mathrm{Bu}$ çalışmada Kienböck hastalığı olan hastalarda kemik grefti kullanmadan uygulanan artroskopik kısmi interkarpal füzyonda elde edilen klinik sonuçlarımız sunuldu.

Hastalar ve yöntemler: Kienböck hastalı̆̆ı olan ve Kasım 2012-Aralık 2013 tarihleri arasında artroskopik lunat eksizyonu ve skafokapitat füzyon uygulanan 11 hasta (6 erkek, 5 kadın; ort. yaş 28.9 yıl; dağılım 14-51 yıl) çalışmaya dahil edildi. Kienböck hastalığının evrelendirilmesinde Bain ve Begg Artroskopik Sınıflaması kullanıldı. Klinik değerlendirme için Hızlı Kol Omuz El Disabiliteleri ve Mayo El Bilek puanlamaları kullanıldı.

Bulgular: İnterkarpal füzyon yaklaşık 7.2 haftada sağlandı. Hastaların ameliyat sonrası üçüncü ve altıncı ay Mayo El Bilek puanları arasında ve ameliyat öncesi ve sonrası Hızlı Kol Omuz El Disabiliteleri puanları arasında istatistiksel olarak anlamlı farklılık vardı. Ameliyat sonrası komplikasyon yoktu.

Sonuç: Çalışma bulgularımıza göre, Kienböck hastalığ olan hastalarda artroskopik kısmi interkarpal füzyon kemik grefti kullanmaksızın gerçekleştirilebilmektedir. Evre 3 ve 4 Kienböck hastalarında bu yöntemle tedavi sonucunda tatmin edici klinik ve fonksiyonel sonuçlar elde edildi.

Anahtar sözcükler: Artrodez; artroskopi; Kienböck hastalığ1; midkarpal füzyon; el bileği.

not clear, but mechanical, traumatic, and vascular factors have been blameworthy. ${ }^{[1]}$

Among the treatment modalities for Kienböck's disease, there are lunate core decompression with

- Received: November 13, 2015 Accepted: March 24, 2016

- Correspondence: Kadir Ertem, MD. İnönü Üniversitesi Tıp Fakültesi Ortopedi ve Travmatoloji Anabilim Dalı, 44315 Malatya, Turkey Tel: +90422 - 3410660/5110 Fax:+90422 - 3410728 e-mail: kadir.ertem@inonu.edu.tr 
Lichtman stage $1-3 \mathrm{~B}^{[3]}$ vascularized bone graft in Lichtman stage $2-3 \mathrm{~A}-\mathrm{B},{ }^{[4]}$ partial capitate shortening in Lichtman stage $2-3 A^{[5]}$ radial shortening in Lichtman stage $3 \mathrm{~B}^{[6]}$ proximal row corpectomy (PRC) in Lichtman stage $3,{ }^{[7]}$ excisional arthroplasty with palmaris longus tendon in Lichtman stage $3,{ }^{[8]}$ and arthroscopic scaphocapitate fusion (SCF) with capitate pole excision in Lichtman stage 3A-B. ${ }^{[9]}$ Recently, with increased use of wrist arthroscopy, a treatment algorithm based on arthroscopy grading system was proposed by Bain and Begg. ${ }^{[10]}$ They suggested PRC or radioscapholunate (RSL) fusion for stage 1 disease, RSL fusion for grade $2 \mathrm{~A}$ and PRC for grade $2 \mathrm{~B}$, and total wrist fusion or hemiarthroplasty for grade 3-4 disease.

Limited intercarpal fusion is an effective surgical procedure for degenerative wrist conditions as Kienböck's disease. ${ }^{[1]]}$ The biomechanical alterations and motion loss after limited fusion of wrist are well presented in the literature. ${ }^{[12-15]}$

There are a number of studies about open procedures; however, to our knowledge, only three studies are available in the literature about arthroscopic limited intercarpal fusion..$^{[9,16-17]}$ Two of these studies used arthroscopic procedure and also graft to enhance intercarpal fusion. In this study, we aimed to present our clinical results obtained in arthroscopic limited intercarpal fusion performed without using bone graft in patients with Kienböck's disease.

\section{PATIENTS AND METHODS}

Arthroscopic SCF was performed in 11 patients with Kienböck's disease (6 males, 5 females; mean age 28.9 years; range 14 to 51 years) between November 2012 and December 2013 at Department of Orthopedics and Traumatology, Medical Faculty of İnönü University. The dominant side was affected in eight patients,

\section{TABLE}

Bain and Begg arthroscopic classification

\begin{tabular}{|c|c|}
\hline Stage & Arthroscopic findings of articular surface \\
\hline 0 & Articular surfaces are normal \\
\hline 1 & Proximal surface of lunate is abnormal \\
\hline $2 \mathrm{~A}$ & $\begin{array}{l}\text { Proximal surface of lunate and lunate fossa of radius } \\
\text { are abnormal }\end{array}$ \\
\hline 2B & Vertical fracture of lunate \\
\hline 3 & $\begin{array}{l}\text { Lunate fossa of radius and proximal and distal } \\
\text { surfaces of lunate are abnormal }\end{array}$ \\
\hline 4 & $\begin{array}{l}\text { Lunate fossa of radius and proximal and distal } \\
\text { surfaces of lunate and the proximal surface of } \\
\text { capitate are abnormal }\end{array}$ \\
\hline
\end{tabular}

while the nondominant side was affected in three patients. Arthrodesis decision was established for stage 3 or 4 Kienböck's disease due to arthroscopic classification described by Bain and Begg (Table I). ${ }^{[10]}$

Pre- and postoperative clinical and radiological assessments were performed for all patients. Clinical evaluation was conducted by Quick Disabilities of Arm, Shoulder and Hand (QuickDASH) and Mayo Wrist scorings. ${ }^{[18,19]}$ Radiological evaluations were performed pre- and postoperatively (Figure 1a, c). Computed tomography was used postoperatively in order to show the cortical healing in fusion site in case of suspicion (Figure 1d). An informed consent was obtained from all patients. The study was conducted in accordance with the principles of the Declaration of Helsinki.

All operations were performed under general anesthesia. Arthroscopic procedure was accomplished as described by Ho. ${ }^{[17]}$ An arm tourniquet was applied. Vertical wrist traction was applied by finger traps to index and middle finger via wrist traction tower (Acumed, Hillsboro, Oregon, USA) (Figure 2a). We did not need any adjustment at the traction tower during the denudation of the intercarpal surfaces (Figure 2b). For distension and washout of the joint, we used continuous saline solution via infusion pump. We routinely used a $2.4 \mathrm{~mm}$ diameter and 30 degree angulated arthroscope. Standard 3-4, 4-5 portals, 6R, midcarpal ulnar (MCU), and midcarpal radial (MCR)
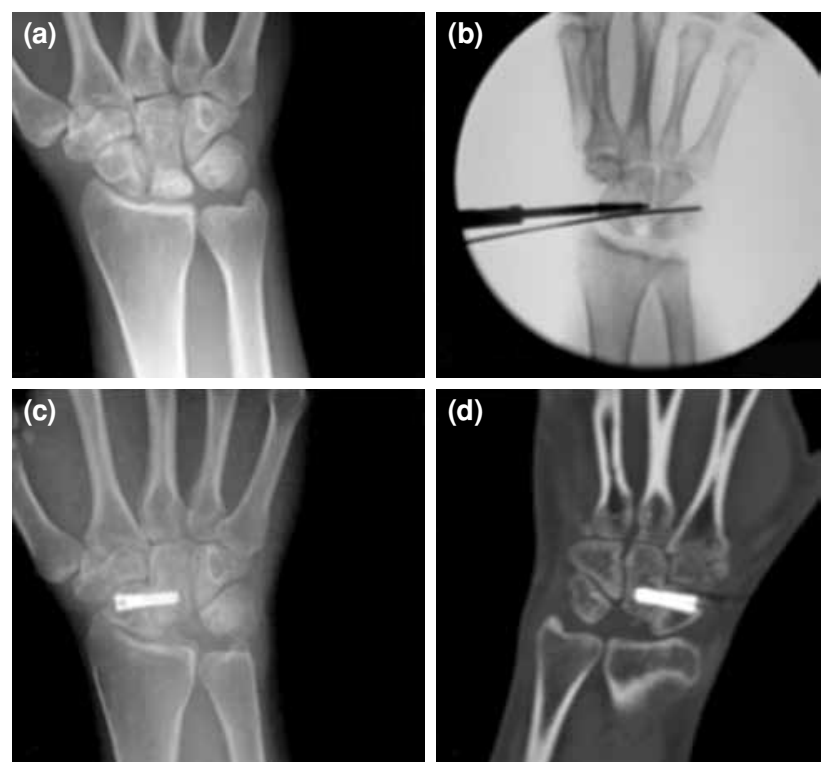

Figure 1. (a) Preoperative anteroposterior X-ray view. (b) Insertion of guide wire and screw under image intensifier between scaphoid and capitate bone. (c) Postoperative anteroposterior X-ray view at sixth month. (d) Postoperative computed tomography view at ninth month. 

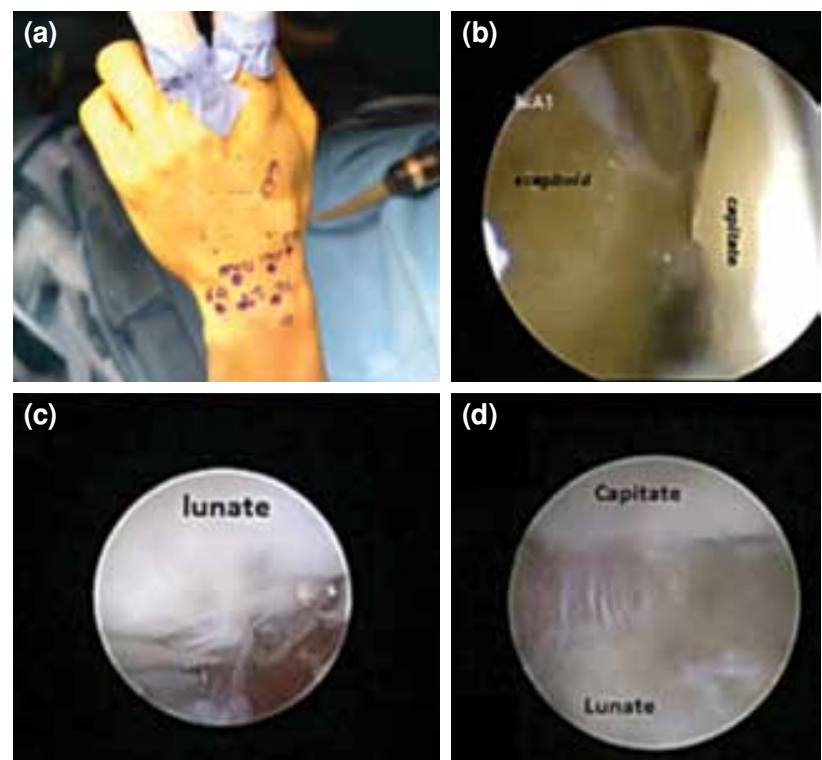

Figure 2. (a) Illustration of marked arthroscopic portals at wrist. (b) Illustration of arthroscopic denudated scaphocapitate joint surfaces. (c) View of lunate surface at radiocarpal portal 3-4 of patient with Kienböck's disease stage 4. (d) View of lunate surface at midcarpal radial portal 3-4 of patient with Kienböck's disease stage 4.

portals were used for examination of bones, joints, and ligaments (Figure 2c, d). After routine arthroscopic examination, synovial hypertrophy was debrided by shaver and rarely by radio frequency probe.

Kienböck's disease stages were assessed arthroscopically. We excised the lunate by $2.7 \mathrm{~mm}$ arthroscopic burr and rongeur through 3-4, 4-5 portals in stage 3 or 4 patients. Then, the denudation of scaphocapitate joint surfaces were accomplished from MCR and MCU for the preparation of arthrodesis (additionally, we used the STT portal at this stage) (Figure 2b). A guide wire was inserted percutaneously under image intensifier between scaphoid and capitate bone (Figure 1b). Headless cannulated screw (Acutrak, Hillsboro, Oregon, USA) was inserted through guide wire. No bone graft was used in our patients and more than one screw was used to achieve a stiffer fixation at the scaphocapitate joint if necessary. So, we used one screw in four patients and two screws in seven patients for fusion. A detailed video presentation of this surgical procedure is available on VuMedi website. ${ }^{[20]}$

A short arm cast was applied to all of the patients for six weeks. At sixth week, if there was union, cast immobilization was abandoned; otherwise, the immobilization time was prolonged until achievement of the radiological finding of fusion (Figure 1c).

\section{Statistical analysis}

For statistical analysis, Wilcoxon signed-rank test was used to compare variables for each group before and after follow-up.

\section{RESULTS}

Demographics and the functional parameters, arthroscopic surgery time (AST) and fusion time of the patients are presented in Table II. The average AST was 123 minutes (range 74 to 210 minutes).

All patients were followed-up in outpatient clinics at two weeks intervals for the first six

TABLE II

Demographics and functional parameters, arthroscopic surgery time, and fusion time of patients

\begin{tabular}{|c|c|c|c|c|c|c|c|c|c|c|c|}
\hline Patient & Age/Gender & Occupation & Smoke & Trauma & Stage* & $\begin{array}{l}\text { AST } \\
(\min )\end{array}$ & $\begin{array}{l}\text { Fusion } \\
\text { time } \\
\text { (week) }\end{array}$ & $\begin{array}{c}\text { DASH- } \\
\text { preoperative }\end{array}$ & $\begin{array}{c}\text { DASH- } \\
\text { postoperative }\end{array}$ & $\begin{array}{c}\text { MAYO } \\
\text { postoperative } \\
3^{\text {rd }} \text { month }\end{array}$ & $\begin{array}{c}\text { MAYO } \\
\text { postoperative } \\
6^{\text {th }} \text { month }\end{array}$ \\
\hline 1 & $51 / \mathrm{M}$ & Blue-collar & - & + & 3 & 192 & 6 & 100 & 70 & 60 & 70 \\
\hline 2 & $24 / \mathrm{M}$ & White-collar & - & - & 3 & 129 & 6 & 82.5 & 75 & 55 & 75 \\
\hline 3 & $46 / \mathrm{F}$ & Housewife & - & - & 3 & 107 & 7 & 58.5 & 75 & 70 & 70 \\
\hline 4 & $28 / \mathrm{M}$ & White-collar & + & - & 3 & 147 & 7 & 75 & 75 & 80 & 80 \\
\hline 5 & $44 / \mathrm{M}$ & Blue-collar & + & - & 4 & 110 & 10 & 75 & 50 & 10 & 70 \\
\hline 6 & $22 / \mathrm{M}$ & Blue-collar & - & - & 4 & 210 & 8 & 50 & 25 & 50 & 50 \\
\hline 7 & $24 / \mathrm{F}$ & Student & - & - & 4 & 74 & 10 & 50 & 0 & 75 & 80 \\
\hline 8 & $24 / M$ & Blue-collar & + & - & 4 & 104 & 6 & 75 & 50 & 60 & 60 \\
\hline 9 & $18 / \mathrm{F}$ & Student & - & - & 3 & 88 & 8 & 75 & 45 & 70 & 75 \\
\hline 10 & $14 / \mathrm{F}$ & Student & - & - & 4 & 98 & 6 & 50 & 25 & 60 & 80 \\
\hline 11 & $23 / \mathrm{F}$ & Student & - & - & 3 & 94 & 6 & 75 & 12.5 & 65 & 70 \\
\hline
\end{tabular}

* Bain and Begg Classification of Kienbock's Diseases; AST: Arthroscopic surgery time; DASH: Disabilities of Arm, Shoulder and Hand. 


\section{TABLE III}

Comparison of pre- and postoperative Disabilities of Arm, Shoulder and Hand scores and postoperative third and sixth months MAYO wrist scores

\begin{tabular}{|c|c|c|c|}
\hline & Preoperative & Postoperative & $p$ \\
\hline & Mean $\pm S D$ & Mean $\pm S D$ & \\
\hline \multicolumn{4}{|c|}{ Patients $(n=11)$} \\
\hline \multirow[t]{2}{*}{ DASH } & $69.3 \pm 15.8$ & $46.1 \pm 26.1$ & 0.009 \\
\hline & $\begin{array}{c}\text { Postoperative } \\
\left.\text { ( } 3^{\text {rd }} \text { months }\right)\end{array}$ & $\begin{array}{c}\text { Postoperative } \\
\left.\text { (6 } 6^{\text {th }} \text { months }\right)\end{array}$ & \\
\hline \multicolumn{4}{|c|}{ Patients $(n=11)$} \\
\hline MAYO & $59.5 \pm 18.6$ & $70.9 \pm 9.1$ & 0.017 \\
\hline
\end{tabular}

weeks postoperatively, then weekly till union was detected on anteroposterior plain radiograph (Figure 1c). Then, they were examined monthly until sixth month. Average follow-up time was 14.4 months (range 6 to 19 months). Union was achieved in all patients in an average of 7.2 weeks (range 6 to 10 weeks). The criteria for union were bridging trabeculae crossing the fracture side on anteroposterior plain radiographs. Average QuickDASH scores improved from preoperative 69.63 (range 50 to 100) to postoperative 45.6 (range 0 to 75 ). Average Mayo Wrist scores were 59.5 (range 10 to 80) and 70.9 (range 55 to 80 ), postoperatively in the third and sixth months, respectively. All patients returned to their previous occupations.

There was a statistically significant difference in Mayo Wrist scores of postoperative third and sixth months as well as pre- and postoperative QuickDASH scores (Table III). No wound infection, nonunion or other complications were noticed. No radioscaphoid arthritis were detected during the evaluation of preand postoperative radiograms of all patients.

\section{DISCUSSION}

The treatment for Kienböck's disease is predominantly guided by symptoms and functional deficits of the patients, likewise by the disease stage. ${ }^{[1]}$ It is not well defined whether surgical treatment methods achieve better results than conservative treatment methods. A great number of the surgical managements had satisfactory clinical and functional results in the literature. ${ }^{[1-9]}$

In this study, satisfactory clinical and functional results were achieved in patients with stage 3 or 4 Kienböck's disease with arthroscopic minimal invasive surgery. To our knowledge, this is the first article presenting arthroscopic SCF without bone graft. It has certain advantages such as shorter operation time and no additional donor site morbidity. We used headless and full threaded compression screws for fixation. Complete fusion was achieved in all of our patients. Duration of operation was about three to four hours at the beginning; however, after the fourth operation, it was reduced to less than two hours. Fusion achieved in 7.2-weeks without bone graft could be attributed to lesser attenuation of osseous vascularization during arthroscopic minimal invasive surgery.

The wrist consists of multiple bony linkages from the forearm to the metacarpus via the carpal bones, and this anatomic peculiarity offers an opportunity to allow fusion of the painful segments of the wrist while preserving motion in other unaffected segments. It also helps to halt any predictable mechanical collapse of the carpal column and maintain carpal height in carpal instability conditions due to failure of ligament constraint or loss of bony integrity such as scaphoid nonunion and Kienböck's disease. ${ }^{[14]}$

Midcarpal arthrodesis with open surgical method is a well-accepted treatment option for advanced carpal collapse. Neubrech et al. ${ }^{[11]}$ retrospectively assessed survival, analyzed complications, and reviewed the long-term follow-up after midcarpal fusion in 572 patients who had undergone 594 four-corner fusions between 1992 and 2001. Of these, 56 patients with 60 midcarpal fusions were accomplished and forty midcarpal fusions (6.7\%) had to be converted into complete wrist arthrodesis. The reasons were ongoing pain in spite of a wellhealed midcarpal fusion or nonunion. Sixty-three patients $(11 \%)$ required revision surgery because of nonunion, hematoma, wound infection (three) or persisting pain. As a result, they suggested that the midcarpal arthrodesis is a long-lasting treatment 
option for advanced carpal collapse and has good long-term results. ${ }^{[1]}$ However, no complications described above were seen in our patients treated by arthroscopic SCF.

The operations described in the literature are mostly open surgeries requiring much soft tissue dissection, including capsular and ligament incisions around the wrist to expose the carpal intervals. This may lead to iatrogenic stiffness of the joint on top of the mechanical constraint rendered by selected carpal fusion. Contrary to open surgery, arthroscopic intervention in partial wrist fusion has potential advantages of minimal surgical damage to the supporting ligaments and capsular structures of the wrist while allowing an unimpeded view to most articular surfaces of the joints and important soft tissue elements. $\mathrm{Ho}^{[17]}$ performed arthroscopic partial wrist fusion in 12 cases, including scaphotrapeziotrapezoid fusion in three cases, scaphoidectomy and $4 \mathrm{CF}$ in four cases, radioscapholunate fusion in three cases, radiolunate fusion in one case, and lunotriquetral fusion in one case. Autogenous cancellous bone graft or bone substitute was inserted and impacted to the fusion site through cannula under direct arthroscopic view. Symptom was resolved or improved, and functional motion was gained in all cases. All surgical scars were almost invisible, and aesthetic outcome was excellent. ${ }^{[17]}$ del Piñal et al. ${ }^{[16]}$ described dry arthroscopic 4CF with bone grafting and presented a technique for dry arthroscopic scaphoidectomy and $4 \mathrm{CF}$, which reduces the operative time to less than two hours. In their series, despite the first operation which lasted four hours, the last two operations were completed in one hour and 45 minutes and one hour 55 minutes, respectively. No complications were noted ${ }^{[16]}$ Leblebicioğlu et al. ${ }^{[9]}$ presented a study on 16 patients with stage 3A or 3B Kienböck's disease. They were randomized to either open SCF and lunate revascularization (group 1) or fully arthroscopic SCF and capitate pole excision (group 2) groups. An autogenous bone graft was used for all cases from ipsilateral distal radius. The average time to radiographically evident fusion was shorter in group 1 (7.25 weeks versus 9 weeks). The mean operating time (153 versus 99 minutes), hospital stay (3.6 versus 2.3 days), and return to unrestricted daily activities (15 versus 5.8 weeks) were shorter in group 2. It was concluded that arthroscopic SCF and capitate pole excision in stages $3 \mathrm{~A}$ and $3 \mathrm{~B}$ Kienböck's disease resulted in shorter operating time, shorter hospital stay, earlier return to unrestricted daily activities, and equal range of motion and grip strength as compared with open SCF and lunate revascularization..$^{[9]}$ Our mean fusion time was shorter than Leblebicioglu's result (7.2 weeks and 9 weeks, respectively). The mean AST for the last two patients was 81 minutes.

The limitations of our study include the small sample size, short follow-up period, and lack of preoperative Mayo Wrist scores.

In conclusion, arthroscopic limited intercarpal fusion without bone graft may be an appropriate method in patients with Kienböck's disease that need limited intercarpal fusion. Being minimally invasive, this method has satisfactory clinical and functional results with high union rate and rare postoperative wound complications.

\section{Declaration of conflicting interests}

The authors declared no conflicts of interest with respect to the authorship and/or publication of this article.

\section{Funding}

The authors received no financial support for the research and/or authorship of this article.

\section{REFERENCES}

1. Beredjiklian PK. Kienböck's disease. J Hand Surg Am 2009;34:167-75.

2. Özçelik İB, Uğurlar M, Kabakaş F, Purisa H. Arthroscopic dorsal ligamento capsulodesis results in Geissler grade 2 and 3 scapholunate interosseous ligament injuries. [Article in Turkish] Eklem Hastalik Cerrahisi 2015;26:6-10.

3. Mehrpour SR, Kamrani RS, Aghamirsalim MR, Sorbi R, Kaya A. Treatment of Kienböck disease by lunate core decompression. J Hand Surg Am 2011;36:1675-7.

4. Ozalp T, Yercan HS, Okçu G. The treatment of Kienböck disease with vascularized bone graft from dorsal radius. Arch Orthop Trauma Surg 2009;129:171-5.

5. Citlak A, Akgun U, Bulut T, Tahta M, Dirim Mete B, Sener M. Partial capitate shortening for Kienböck's disease. J Hand Surg Eur Vol 2015;40:957-60.

6. Altay T, Kaya A, Karapinar L, Ozturk H, Kayali C. Is radial shortening useful for Litchman stage 3B Kienbock's disease? Int Orthop 2008;32:747-52.

7. Buluç L, Gündeş H, Baran T, Selek Ö. Proximal row carpectomy for Lichtman stage III Kienböck's disease. Acta Orthop Traumatol Turc 2015;49:641-7.

8. Küçük L, Ozdemir O, Coşkunol E, Süğün TS, Ozaksar K. The effect of excisional arthroplasty with palmaris longus tendon on carpal height ratio in Stage 3 Kienböck's disease. Acta Orthop Traumatol Turc 2011;45:393-8.

9. Leblebicioğlu G, Doral MN, Atay A öA, Tetik O, Whipple TL. Open treatment of stage III Kienböck's disease with lunate revascularization compared with arthroscopic treatment without revascularization. Arthroscopy 2003;19:117-30.

10. Bain GI, Begg M. Arthroscopic assessment and classification of Kienbock's disease. Tech Hand Up Extrem Surg 2006;10:8-13.

11. Neubrech F, Mühldorfer-Fodor M, Pillukat T, Schoonhoven Jv, Prommersberger KJ. Long-term results after midcarpal 
arthrodesis. J Wrist Surg 2012;1:123-8.

12. Garcia-Elias M, Cooney WP, An KN, Linscheid RL, Chao EY. Wrist kinematics after limited intercarpal arthrodesis. J Hand Surg Am 1989;14:791-9.

13. Iwasaki N, Genda E, Barrance PJ, Minami A, Kaneda K, Chao EY. Biomechanical analysis of limited intercarpal fusion for the treatment of Kienböck's disease: a threedimensional theoretical study. J Orthop Res 1998;16:256-63.

14. Krimmer $\mathrm{H}$, Wiemer $\mathrm{P}, \mathrm{Kalb} \mathrm{K}$. Comparative outcome assessment of the wrist joint--mediocarpal partial arthrodesis and total arthrodesis. Handchir Mikrochir Plast Chir 2000;32:369-74. [Abstract]

15. Siegel JM, Ruby LK. A critical look at intercarpal arthrodesis: review of the literature. J Hand Surg Am 1996;21:717-23.

16. del Piñal F, Klausmeyer M, Thams C, Moraleda E, Galindo
C. Early experience with (dry) arthroscopic 4-corner arthrodesis: from a 4-hour operation to a tourniquet time. J Hand Surg Am 2012;37:2389-99.

17. Ho PC. Arthroscopic partial wrist fusion. Tech Hand Up Extrem Surg 2008;12:242-65.

18. Hudak PL, Amadio PC, Bombardier C. Development of an upper extremity outcome measure: the DASH (disabilities of the arm, shoulder and hand) [corrected]. The Upper Extremity Collaborative Group (UECG) Am J Ind Med 1996;29:602-8.

19. Amadio PC, Berquist TH, Smith DK, Ilstrup DM, Cooney WP, Linscheid RL. Scaphoid malunion. J Hand Surg Am 1989;14:679-87.

20. Available from: https://www.vumedi.com/video/ arthroscopic-lunate-excision-and-scapholunatearthrodesis-in-Kienböck-disease/ 